\title{
Gracilaria chilensis: Bioethanol Production and By-Product Characterization
}

\section{Carmen Gloria Seguel ${ }^{1 *}$, Emilio Soto ${ }^{1}$ and José Rojas ${ }^{2}$}

${ }^{1}$ Tarapaca University, Department of Chemistry, Faculty of Science, Avda, General Velasquez 1775, Arica, Chile

${ }^{2}$ Technological University of Chile, INACAP, Av, Santa Maria 2190, Arica, Chile

\begin{abstract}
One of the most important challenges for the new global economy is to find new sources of bioenergy. Due to its photosynthetic efficiency and the possibility of biotransformation of its carbohydrates into bioethanol, seaweed plays an important role as a source of renewable biomass fuel.

This paper aims firstly to assess Gracilaria chilensis (red algae) as a substrate for bioethanol production by using anaerobic fermentation with Saccharomyces cerevisiae, and then to characterize the by-products of this biotransformation.

The main stage in the generation of solid byproducts is the hydrolysis with a yield about $50 \%$ w/w dry weigh. This by-product contains: fiber $(42.7 \% \mathrm{w} / \mathrm{w})$, proteins $(39.95 \% \mathrm{w} / \mathrm{w})$, carbohydrates $(6.43 \% \mathrm{w} / \mathrm{w})$, lipids $(5.77 \% \mathrm{w} / \mathrm{w})$, ashes $(5.15 \% \mathrm{w} / \mathrm{w})$ and a percentage of micronutrients $\mathrm{P}>\mathrm{K}>\mathrm{Ca}>\mathrm{Mg}>\mathrm{Na}$ in minor quantity than $\mathrm{G}$. chilensis biomass.
\end{abstract}

Keywords: Seaweed; Bioethanol; By-products; Fermentation Gracilaria chilensis; Biotechnology

\section{Introduction}

The production of biofuels is generating worldwide interest in economic, environmental, institutional, and political circles, particularly in countries that are not self-sufficient in their supply of fossil fuel resources. As a result, there is a growing need to investigate local resources and diversify their energy-production technology.

Currently, there is a growing interest in combining the use of macroalgae in the food industry with the development of research into industrial bioenergy production. Seaweeds have several advantages, including the fact that they can be grown in three dimensions, which allow them to produce more biomass per hectare compared with terrestrial plants. In addition, macroalgal biomass generally has a high content of hydrolysable carbohydrates, which makes these algae an important raw material for bioethanol production [1].

Red algae are rich in polysaccharides ( $40 \%$ to $76 \%$ of dry weight), which are mostly distributed in the cell wall and in the form of carrageenan and agar as galactans and sulfated glucans [2]. Recent evidence suggests that the amount of bioenergy produced by red algae biomass is higher than any other source of biomass [3].

Some studies with Gracialaria sp. biomass for bioethanol production has been done, nevertheless both hydrolysis and fermentation methods are still under discussion because of long periods of sacharification (different acid and enzymatic conditions) as well as the need to improve the fermentative stages to achieve simpler processes with lower productive costs.

Chile has a large coastline that extends over $4,300 \mathrm{~km}$, marine biomass (algae in particular) becoming the leading producer of read algae Gracilaria chilensis, which could be an excellent raw material for bioenergy generation.

The aim of the present research was to use Gracilaria chilensis as a new substrate for bioethanol production, applying the easiest hydrolysis method with the highest extraction yield of carbohydrate for the fermentation step with Saccharomyces cerevisiae and carry out the chemical characterization of by-products generated from bioethanol conversion processes.

\section{Materials and Methods}

\section{Collection and size-fractionation of feedstock}

Fresh samples of the macroalgae Gracilaria chilensis were collected in August 2010 in sector $41^{\circ} 51^{\prime} 07^{\prime \prime}$ south latitude and $73^{\circ} 58^{\prime} 30^{\prime \prime}$ east longitude in the $\mathrm{X}$ Region, Chile. The algae were washed and air-dried for 24 hours followed by oven incubation at $45 \pm 1^{\circ} \mathrm{C}$ for $5 \mathrm{~h}$. The dried algae was reduced in size to approximately $7 \mathrm{~mm}$ and stored at $-20^{\circ} \mathrm{C}$ in polyethylene bags until use.

\section{Chemical analysis}

The moisture content of macroalgae samples was determined following the gravimetric method [4].

The total ash, lipids and proteins content was assessed according to standard methods [5]. Total carbohydrate content was determined using the phenol-sulfuric acid method [6] and fiber by difference.

\section{Micronutrients analysis}

The micronutrients: $\mathrm{K}, \mathrm{Mg}, \mathrm{Ca}, \mathrm{Na}$, of $\mathrm{G}$. chilensis and solid byproduct was carried out using an atomic absorption spectrophotometer. All measurements were performed using standard flame operating conditions, as recommended by the manufacturer and calibration of measurements was carried out using commercial standards. The determination of phosphorus was performed by employing molybdenum blue method at $730 \mathrm{~nm}$ [7].

*Corresponding author: Dr. Carmen Gloria Seguel, University of Tarapacá, Department of Chemistry, Faculty of Science, Avda, General Velasquez 1775 Arica, Chile, Tel: +56 58 2205448, Fax: +56 58 2205424, E-mail: cseguel@uta.cl

Received April 30, 2015; Accepted May 27, 2015; Published May 31, 2015

Citation: Seguel CG, Soto E, Rojas J (2015) Gracilaria chilensis: Bioethanol Production and By-Product Characterization. J Coast Zone Manag 18: 403. doi: 10.4172/2473-3350.1000403

Copyright: (C) 2015 Seguel CG, et al. This is an open-access article distributed under the terms of the Creative Commons Attribution License, which permits unrestricted use, distribution, and reproduction in any medium, provided the original author and source are credited. 


\section{Acid thermal hydrolysis}

For the acid hydrolysis, $50 \mathrm{~g}$ of dry macroalgae were suspended in $500 \mathrm{ml} 1 \mathrm{M} \mathrm{H}_{2} \mathrm{SO}_{4}$ and macerated at $70^{\circ} \mathrm{C}$ with constant shaking about $(200-400 \mathrm{rpm}$ for 3 to $5 \mathrm{~h})$. The mixture was cooled at room temperature and centrifuged at $6000 \mathrm{~g}$ for $10 \mathrm{~min}$. The liquid phase was stored at $4^{\circ} \mathrm{C}$ for further analysis of the carbohydrates and proteins as described previously and the solid phase was dried at $45^{\circ} \mathrm{C}$ until constant weight and screened through 45-35 mesh sieves. Proximate composition of powdered solid by-product was analyzed as described above.

\section{Culture conditions and fermentation}

S. cerevisiae (lyophilized commercial) was cultured on agar plates as described by Lee et al. [8]. An E-flask $250 \mathrm{~mL}$ containing $100 \mathrm{~mL}$ of sterile YEPD medium [9] was inoculated with S. cerevisiae and incubated at $37^{\circ} \mathrm{C}$ with agitation $(180 \mathrm{rpm}$ for $24 \mathrm{~h})$. Cell growth $(\mathrm{g} / \mathrm{L})$ was monitored by measuring at $600 \mathrm{~nm}$ (OD600).

\section{Fermentation liquid hydrolysis (LH)}

The Liquid Hydrolysis (LH) was diluted to a final concentration of carbohydrate $2 \%(\mathrm{w} / \mathrm{v})$ and subsequently sterilized at $121{ }^{\circ} \mathrm{C}$ for 30 min and transferred into E-flask $1000 \mathrm{~mL}$ for anaerobic fermentation at $\mathrm{pH}$ 5.0. The mixture was inoculated with $10 \%(\mathrm{v} / \mathrm{v})$ of $S$. cerevisiae precultured and incubated at $27^{\circ} \mathrm{C}$ in an orbital shaker at $250 \mathrm{rpm}$ for $30 \mathrm{~h}$.

The monitoring of the individual fermentation reactions was carried out at distinct time intervals over $40 \mathrm{~h}$. The number of cell per $\mathrm{mL}$ was determined using a Neubauer chamber and yeast biomass content $(\mathrm{g} / \mathrm{L})$ by measuring the optical density OD600. The samples were centrifuged at $10,000 \mathrm{~g}$ for $2 \mathrm{~min}$ and supernatants were reserved for carbohydrates consumption analysis as described above and the ethanol produced (expressed in $\mathrm{gL}^{-1}$ ) by Conway micro-diffusion technique [10].

\section{Results and Discussion}

\section{Chemical composition}

The proximate composition of $G$. chilensis showed a high carbohydrate content per dry weight $(48.7 \% \mathrm{w} / \mathrm{w})$ (Table 1$)$. These results presented good concordance with those reported by Ortiz [11]. However, the carbohydrate content determined in this research is approximately $30 \% \mathrm{w} / \mathrm{w}$ lower compared with those reported for Gracilaria sp. [12].

As it is well known, the algae carbohydrate quality and quantity strongly depend on different environmental physicochemical growth parameters, such as farming location, harvest season [13] and these can explain the differences between Gracilaria species.

The proximal composition of the by-product of hydrolysis shows an increment of percentage of fibers $>$ proteins $>$ lipids $>$ ashes. The variation of the quantities of different components is explained the reduction of carbohydrates content $(6.43 \% \mathrm{w} / \mathrm{w})$ in the by-product (Table 1).

\section{Micronutrients analysis of $\mathrm{G}$. chilensis and by-product}

The micronutrients analysis of $G$. chilensis showed the following composition order: $\mathrm{Na}>\mathrm{K}>\mathrm{P}>\mathrm{Mg}>\mathrm{Ca}$ (Table 1). $\mathrm{Na}$ and $\mathrm{K}$ present a positive correlation with other species of Gracilaria [14] and red algae [15].

Micronutrients content of solid by-product after acid thermal hydrolysis are lower than G. chilensis biomass, following the composition order $\mathrm{P}>\mathrm{K}>\mathrm{Ca}>\mathrm{Mg}>\mathrm{Na}$ (Table 1). The variation of percentages of these micronutrients can be explained the by chemical activity of $\mathrm{H}_{2} \mathrm{SO}_{4}$.

\section{Characterization Hydrolysis liquid (HL) and by-products}

The depolymerization of the sulfated carbohydrates present in four samples of $G$. chilensis was highly influenced by a gentle agitation of the biomass under acid thermal hydrolysis. This process led to two formations: a dark liquid that was used for fermentation and other corresponding to a solid by-product.

The hydrolysis average yield was $90.84 \% \mathrm{w} / \mathrm{w}$ (Table 2) and higher comparing those carried out with a combined thermic process with autoclave [16] and enzymatic hydrolysis acid of Gracilaria sp. ( $\otimes 80 \%$ $\mathrm{w} / \mathrm{w})$ reported by $\mathrm{Wu}$ et al. [12].

This hydrolysis process allows recovery of an average of about 46.88 $\%$ dry weigh of the solid biomass as a by-product with a low content of carbohydrate (6.43\%). The carbohydrate content depletion increases the percentage of other components, and the microelements content shown a diminishing of their percentage under acid conditions, particularly the Na quantity (Table 1).

\section{Fermentation monitoring}

Hydrolysis liquid (HL) from four macroalgae G. chilensis samples with carbohydrate concentrations in the range of $22.33 \pm 0.01 \mathrm{gL}^{-1}$ were fermented with $S$. cerevisiae, The monitoring of ethanol-production is given in Figure 1. The carbohydrates presented a rapid degradation between 0 and $19 \mathrm{~h}$, associated to the higher metabolic activity of the microorganism and a maximal ethanol production of $8.94 \mathrm{gL}^{-1}$. The remaining carbohydrate concentration was $1.91 \% \mathrm{w} / \mathrm{w}$ of the initial substrate concentration. The fermentation average yield was $86.64 \%$ $\mathrm{w} / \mathrm{w}$ (Table 2) with a production of $0.44 \mathrm{~g}$ ethanol/g carbohydrate consumed. These results are very promising considering the low initial carbohydrate content and are in the same range as those reported by

\begin{tabular}{|c|c|c|}
\hline $\begin{array}{c}\text { Components }(\% \\
\text { w/w) }\end{array}$ & G. chilensis & By-product \\
\hline Moisture & $90.19 \pm 0.92$ & $96.05 \pm 0.19$ \\
\hline Ash & $21.44 \pm 0.33$ & $5.15 \pm 0.11$ \\
\hline Lipids & $0.48 \pm 0.01$ & $5.77 \pm 0.09$ \\
\hline Proteins & $17.63 \pm 0.11$ & $39.95 \pm 0.09$ \\
\hline Fiber & $11.79 \pm 0.59$ & $42.7 \pm 0.43$ \\
\hline Carbohydrates & $48.66 \pm 0.14$ & $6.43 \pm 0.41$ \\
\hline Ca & $0.21 \pm 0.01$ & $0.13 \pm 0.01$ \\
\hline Mg & $0.24 \pm 0.01$ & $0.12 \pm 0.01$ \\
\hline $\mathrm{K}$ & $5.37 \pm 0.01$ & $1.31 \pm 0.01$ \\
\hline $\mathrm{P}$ & $1.74 \pm 0.01$ & $2.35 \pm 0.01$ \\
\hline $\mathrm{Na}$ & $12.53 \pm 0.03$ & $0.06 \pm 0.01$ \\
\hline
\end{tabular}

Values expressed in dry matter; Results expressed as mean \pm SD of triplicates Table 1: Chemical Composition of $G$. chilensis and by-product obtained from hydrolysis process.

\begin{tabular}{|c|c|c|}
\hline Hydrolysis liquid $(\mathrm{HL})$ & $\begin{array}{c}\text { Hydrolysis Yield } \\
(\% \mathrm{w} / \mathrm{w})\end{array}$ & $\begin{array}{c}\text { Fermentation Yield } \\
(\% \mathrm{w} / \mathrm{w})\end{array}$ \\
\hline 1 & 90.34 & 88.24 \\
\hline 2 & 92.05 & 86.11 \\
\hline 3 & 90.38 & 84.16 \\
\hline 4 & 90.45 & 88.06 \\
\hline
\end{tabular}

Table 2: Yield of hydrolysis and fermentation processes of G. chilensis 
Citation: Seguel CG, Soto E, Rojas J (2015) Gracilaria chilensis: Bioethanol Production and By-Product Characterization. J Coast Zone Manag 18: 403. doi: $10.4172 / 2473-3350.1000403$

Page 3 of 3


Figure 1: Monitoring of fermentation process of Gracilaria chilensis with Saccharomyces cerevisiae

Wu et al. [12].

As far the by-products of the fermentation process these were mainly remains of $S$. cerevisiae yeast with higher content of proteins (results are not shown).

\section{Conclusions}

This is the first report about Gracilaria chilensis bioethanol production and by-products with their corresponding characterization.

The production of bioethanol using G. chilensis was $0.18 \mathrm{~g}$ ethanol $/ \mathrm{g}$ dry seaweed with a yield of $86.64 \% \mathrm{w} / \mathrm{w}$.

The mechanical agitation was essential to simplify the stage of hydrolysis to moderate acid and temperature conditions leading to a hydrolysis yield $91 \% \mathrm{w} / \mathrm{w}$.

The use of G. chilensis as substrate for bioethanol production allows to recovery almost $50 \%$ of seaweed as by-products which could have potential biotechnological applications.

\section{Acknowledgements}

This work was supported by the Chilean National Research Foundation FONDEF D06i1099 and UTA Mayor Program Research.

\section{References}

1. Yoon J, Kim S, Ryu J, Choi G, Shim M (2010) Production of polysaccharides and corresponding sugars from red seaweed. Adv Mater Res 93-94: 463466.

2. Sebaaly C, Karaki N, Chahine N (2012) Polysaccharides of the red algae "Pterocladia" growing on the Lebanese coast: isolation, structural features with antioxidant and anticoagulant activities. J Appl Pharm Sci 2: 1-10.

3. Wi S, Kim S, Ryu H, Choi J, Kim G, Shin M (2009) The potential value of the seaweed Ceylon moss (Gelidium amansii) as alternative bioenergy resources. Bioresour Technol 100: 6658-6660.

4. Nielsen S (2009) Food Analysis Laboratory Manual (4 ${ }^{\text {th }}$ edn.) Springer, New York.

5. AOAC (2005) Official Methods of Analysis Association of AOAC International, $\left(18^{\text {th }}\right.$ edn). Washington, DC: Association of Official Analytical Chemists.

6. Dubois M, Gilles K, Hamilton J, Rebers P, Smith F (1956) Colorimetric method for determination of sugars and related substances. Anal Chem 28: 350-356.

7. Instituto de Salud Pública (ISP) (2009) Procedimiento de determinación de fósforo total en alimentos. Método espectrofotométrico de molibdato de amonio. Gobierno de Chile.

8. Lee J, Pan L, Lee J, Ruy H, Kyeong K (2013) Ethanol production from Saccharina japonica using an optimized extremely low acid pretreatment followed by simultaneous saccharification and fermentation. Bioresource Technology 127: 119-125.

9. Ge L, Wang P, Mou H (2011) Study on saccharification techniques of seaweed wastes for the transformation of ethanol. Renewable Energy 36: 84-89.

10. 10. Winnick T (1942) Determination of Ethyl Alcohol by Microdiffusion. Ind Eng Chem Anal Ed 14: 523-525.

11. Jaime Ortiz $V$ (2011) Composición nutricional de algas rodoficeas chilenas Monografía, Facultad de Ciencias Químicas y Farmacéuticas de Chile, Santiago.

12. Wu F, Wu J, Liao Y, Wang M, Shih I (2014) Sequential acid and enzymatic hydrolysis in situ and bioethanol production from Gracilaria biomass. Bioresour. Technol 156:123-131.

13. Adams J, Ross A, Anastasakis K, Hodgson E, Gallagher J, et al. (2011) Seasonal variation in the chemical composition of the bioenergy feedstock Laminaria digitata for thermochemical conversion. Bioresour Technol 102 226-234.

14. Sakthivel R, Devi K (2015) Evaluation of physicochemical properties, proximate and nutritional composition of Gracilaria edulis collected from Palk Bay. Food Chemistry 174: 68-74.

15. Larrea M, Pomares M, Gómez M, Sánchez F, Ródenas S (2010) Validation of an ICP-OES method for macro and trace element determination in Laminaria and Porphyra seaweeds from four different countries. Journal of Food Composition and Analysis 23: 814-820.

16. Jang S, Shirai Y, Uchida M, Wakisaka M (2012) Production of mono sugar from acid hydrolysis of seaweed. Afr J Biotechnol 11: 1953-1963. 